\title{
$\beta$ Blockade after myocardial infarction: systematic review and meta regression analysis
}

\author{
Nick Freemantle, John Cleland, Philip Young, James Mason, Jane Harrison
}

\begin{abstract}
Medicines
Evaluation Group,

Centre for Health

Economics,

University of York,

York YO10 5DD

Nick Freemantle,

senior research fellow

James Mason,

senior research fellow

Jane Harrison,

information officer

Department of

Cardiology, Castle

Hill Hospital,

University of Hull,

Kingston upon

Hull, U16 5JQ

John Cleland,

professor

Department of

Health Sciences

and Clinical

Evaluation,

University of York

Philip Young,

lecturer in applied

statistics

Correspondence to:

$\mathrm{N}$ Freemantle

meg@york.ac.uk
\end{abstract}

BMJ 1999;318:1730-7

website

extra

References for the trials appear on the BMJ's website

www.bmj.com

\begin{abstract}
Objectives To assess the effectiveness of $\beta$ blockers in short term treatment for acute myocardial infarction and in longer term secondary prevention; to examine predictive factors that may influence outcome and therefore choice of drug; and to examine the clinical importance of the results in the light of current treatment.

Design Systematic review of randomised controlled trials.

Setting Randomised controlled trials.

Subjects Patients with acute or past myocardial infarction.

Intervention $\beta$ Blockers compared with control. Main outcome measures All cause mortality and non-fatal reinfarction.

Results Overall, 5477 of 54234 patients (10.1\%) randomised to $\beta$ blockers or control died. We identified a $23 \%$ reduction in the odds of death in long term trials $(95 \%$ confidence interval $15 \%$ to $31 \%$ ), but only a $4 \%$ reduction in the odds of death in short term trials $(-8 \%$ to $15 \%)$. Meta regression in long term trials did not identify a significant reduction in effectiveness in drugs with cardioselectivity but did identify a near significant trend towards decreased benefit in drugs with intrinsic sympathomimetic activity. Most evidence is available for propranolol, timolol, and metoprolol. In long term trials, the number needed to treat for 2 years to avoid a death is 42 , which compares favourably with other treatments for patients with acute or past myocardial infarction. Conclusions $\beta$ Blockers are effective in long term secondary prevention after myocardial infarction, but they are underused in such cases and lead to avoidable mortality and morbidity.
\end{abstract}

\section{Introduction}

$\beta$ Blockade was once heralded as a major advance in the treatment of patients with myocardial infarction, but current evidence suggests that less than half of eligible patients receive it. ${ }^{1-3}$ The effectiveness of $\beta$ blockers was appraised by Yusuf et al in $1985,{ }^{4}$ but since then there have been nearly 3000 deaths among 23000 patients randomised in new trials. Trials of $\beta$ blockers now include a broader group of patients such as those at high risk or with accompanying heart failure, enabling the benefits identified by Yusuf et $\mathrm{al}^{4}$ in a restricted group of trials to be extended to such patients.

Methods used in systematic reviews have also advanced. The development of regression techniques within meta analysis enables a more robust examination of the importance of factors that may mediate upon the effectiveness of specific drugs. ${ }^{5}$ Two such factors, intrinsic sympathomimetic activity and cardioselectivity, were identified as potentially important, ${ }^{4}$ and intrinsic sympathomimetic activity in particular seemed to be related to reduced therapeutic action. Given the changing use of drugs after myocardial infarction, the early promise of $\beta$ blockade in these patients, and the continuing high rates of mortality associated with myocardial infarction, a new overview of these drugs is timely.

\section{Methods}

Objective

We reappraised the effectiveness of $\beta$ blockers for secondary prevention after myocardial infarction. Our main outcome was all cause mortality and the secondary outcomes were non-fatal reinfarction and withdrawal from treatment. We examined the effectiveness of $\beta$ blockers in the acute phase immediately after myocardial infarction; their role in longer term secondary prevention; the importance of early initiation after the onset of symptoms; the extent to which specific pharmacological features of different $\beta$ blockers may affect their performance; the magnitude of benefits achieved by $\beta$ blockers; and the clinical importance of $\beta$ blockers.

\section{Inclusion criteria}

We included randomised trials without crossover, with treatment lasting more than one day, and with follow up that examined the clinical effectiveness of $\beta$ blockers versus placebo or alternative treatment in patients who had had a myocardial infarction. Treatment may have begun at any stage before or after myocardial infarction and may have been commenced intravenously.

\section{Search strategy}

We conducted sensitive electronic searches of Medline (1966-97 through Ovid), Embase (1974-97 through Dialog), Biosis (1985-97 through Edina), Healthstar (1975-97 through Ovid), Sigle (1980-97 through Blaise-line), IHTA (1990-97 through ECRInet), conference papers index (1984-97 through Dialog), Derwent drug file (1992-97 through Dialog), dissertation abstracts (1992-97 through Dialog), Pascal (1992-97 through Dialog), international pharmaceutical abstracts (1992-97 through Dialog), and science citation index (1981-97 through BIDS).

We reviewed the reference list of each identified study. We also examined existing bibliographies and reviews for relevant studies.

Data abstraction and appraisal of study quality From each study we abstracted data on the total number of patients randomised to active treatment or control, $\beta$ blocker, route and dose of drug, duration of treatment, loss to follow up, level of blinding, concealment of allocation, ${ }^{6}$ specific study inclusion and exclusion criteria, duration of follow up, deaths, reinfarc- 
Table 1 Characteristics of short term trials comparing $\beta$ blockers with control (see website for references)

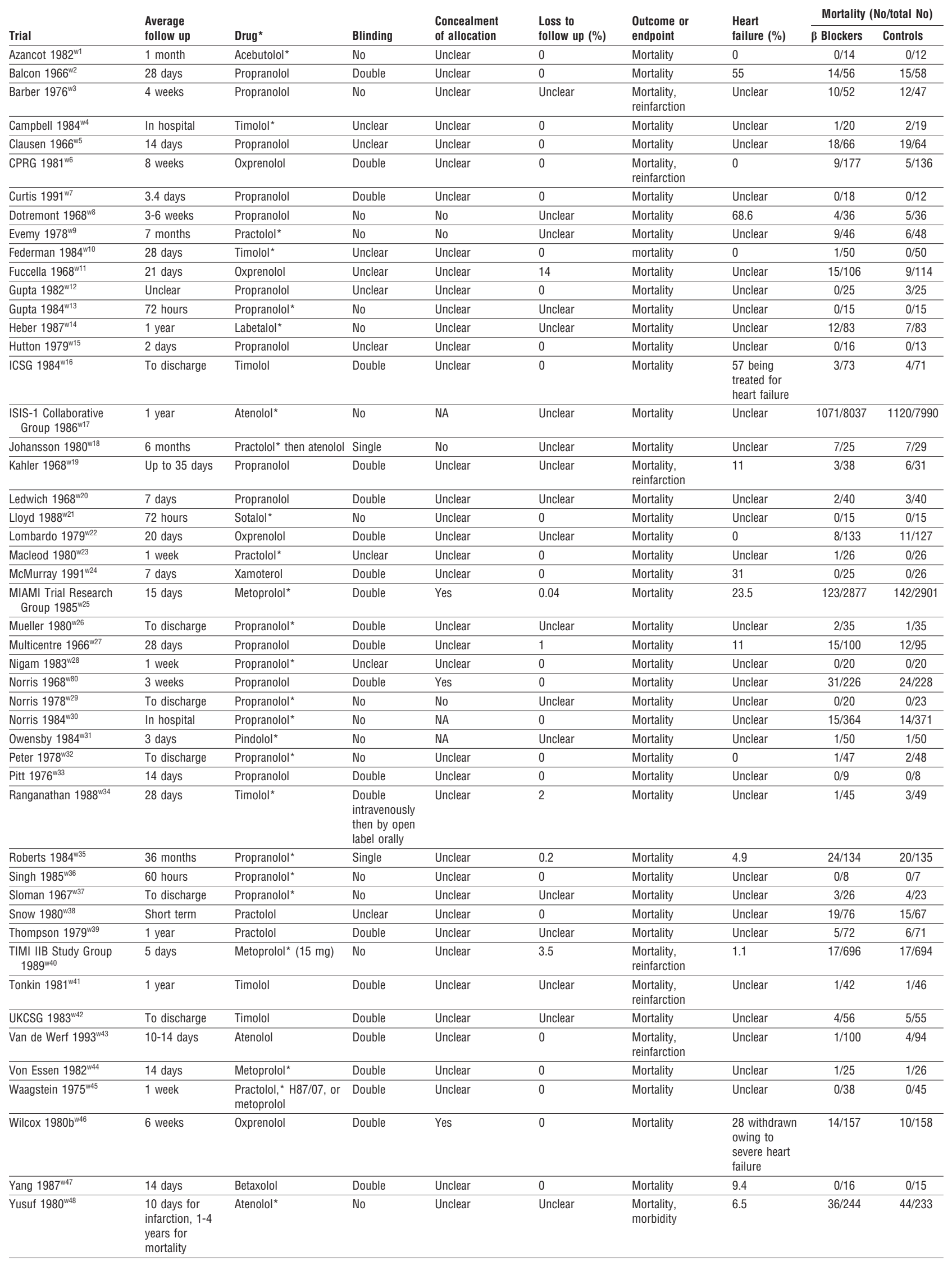

CPRG=Coronary Prevention Research Group; ICSG=International Collaborative Study Group; ISIS-1=first international study of infarct survival; MIAMI=metoprolol in acute myocardial infarction; TIMI IIB=thrombolysis in myocardial infarction phase II trial; UKCSG=UK Collaborative Study Group. *Initial dose intravenously. 


\begin{tabular}{|c|c|c|c|c|}
\hline Trial & & & eight (\%) & Odds ratio $(95 \% \mathrm{Cl})$ \\
\hline Van de Werf $1993^{\text {w43 }}$ & +1 & & 0.3 & 0.23 (0.00 to 2.37$)$ \\
\hline Yusuf $1980^{w 48}$ & $\square$ & & 2.8 & $0.74(0.44$ to 1.24$)$ \\
\hline ISIS-1 Collaborative Group 1986w17 & s & & 71.1 & 0.94 (0.86 to 1.03$)$ \\
\hline Atenolol pooled & & & 74.2 & 0.93 (0.85 to 1.02$)$ \\
\hline Heber 1987w14 & प & + & 0.4 & 1.84 (0.62 to 5.81$)$ \\
\hline Labetalol pooled & & $D$ & 0.4 & 1.84 (0.62 to 5.81$)$ \\
\hline Von Essen $1982^{\text {w44 }}$ & - & E & 0.1 & 1.04 (0.01 to 85.00$)$ \\
\hline TIMI IIB Study Group 1989w40 & $\square$ & $\sqsupset$ & 1.2 & $1.00(0.47$ to 2.10$)$ \\
\hline MIAMI Trial Research Group 1985 w25 & 曲 & & 9.9 & 0.87 (0.67 to 1.12$)$ \\
\hline Metoprolol pooled & & & 11.2 & 0.88 (0.70 to 1.11$)$ \\
\hline CPRG 1981w6 & $\square$ & 1 & 0.4 & 1.40 (0.41 to 5.46$)$ \\
\hline Fuccella 1968w11 & 4 & 1 & 0.5 & 1.92 (0.74 to 5.22$)$ \\
\hline Wilcox 1980b"w46 & 正 & 1 & 0.7 & 1.45 (0.58 to 3.77$)$ \\
\hline Lombardo 1979 w22 & +1 & $\sqsupset$ & 0.8 & 0.67 (0.23 to 1.92$)$ \\
\hline Oxprenolol pooled & & D & 2.4 & $1.30(0.82$ to 2.05$)$ \\
\hline Owensby $1984^{w 31}$ & & 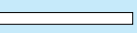 & 0.1 & 1.00 (0.01 to 80.08$)$ \\
\hline Pindolol pooled & 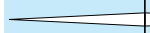 & $=$ & 0.1 & 1.00 (0.01 to 80.08$)$ \\
\hline Evemy $1978^{\text {w9 }}$ & $\square$ & + & 0.3 & $1.70(0.48$ to 6.37$)$ \\
\hline Johansson 1980w18 & + & $\square$ & 0.3 & $1.22(0.30$ to 4.94$)$ \\
\hline Thompson 1979 w39 & $\square$ & $\square$ & 0.4 & 0.81 (0.19 to 3.36$)$ \\
\hline Snow 1980w38 & $\longrightarrow$ & 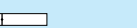 & 0.9 & 1.16 (0.50 to 2.72$)$ \\
\hline Practolol pooled & & $D$ & 2.0 & 1.23 (0.74 to 2.04$)$ \\
\hline Mueller 1980w26 & & + & 0.1 & $2.06(0.10$ to 125.09$)$ \\
\hline Peter 1978 w32 & +1 & & 0.1 & 0.50 (0.01 to 9.99$)$ \\
\hline Ledwich 1968w20 & +1 & $\square$ & 0.2 & $0.65(0.05$ to 6.04$)$ \\
\hline Gupta 1982w12 & & & 0.2 & Not estimable \\
\hline Sloman 1967w37 & +1 & $\square$ & 0.3 & 0.62 (0.08 to 4.21$)$ \\
\hline Dotremont 1968w8 & & $\square$ & 0.3 & 0.78 (0.14 to 3.99$)$ \\
\hline Kahler $1968^{w 19}$ & 1 & $\square$ & 0.4 & 0.36 (0.05 to 1.89$)$ \\
\hline Barber 1976 w3 & $\square$ & $\sqsupset$ & 0.7 & 0.69 (0.24 to 2.00$)$ \\
\hline Bath 1966 w27 & $\square$ & 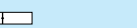 & 0.8 & $1.22(0.50$ to 3.04$)$ \\
\hline Balcon 1966w2 & $\square$ & $\square$ & 0.8 & 0.96 (0.38 to 2.42$)$ \\
\hline Norris 1984 w30 & $\square$ & $\square$ & 1.0 & 1.10 (0.49 to 2.49$)$ \\
\hline Clausen $1966^{\text {w5 }}$ & $\square$ & $\square$ & 1.0 & 0.89 (0.39 to 2.04$)$ \\
\hline Roberts $1984^{w 35}$ & 十 & $\square$ & 1.2 & 1.25 (0.62 to 2.54$)$ \\
\hline Norris 1968 & & \pm & 1.5 & 1.35 (0.74 to 2.50$)$ \\
\hline Propranolol pooled & & $>$ & 8.7 & $1.00(0.77$ to 1.28$)$ \\
\hline Tonkin 1981w41 & & & 0.1 & $1.10(0.01$ to 88.04$)$ \\
\hline Campbell 1984w4 & t & $\square$ & 0.1 & 0.45 (0.01 to 9.51$)$ \\
\hline Ranganathan 1988w34 & 1 & $\square$ & 0.2 & 0.35 (0.01 to 4.57$)$ \\
\hline ICSG 1984w16 & & $\square$ & 0.3 & $0.72(0.10$ to 4.43$)$ \\
\hline UKCSG 1983 w42 & $\square+$ & $\square$ & 0.3 & 0.77 (0.14 to 3.81$)$ \\
\hline Timolol pooled & $<1$ & $>$ & 1.0 & $0.72(0.32$ to 1.60$)$ \\
\hline Fixed effects pooled & & & 100 & 0.95 (0.88 to 1.02$)$ \\
\hline Full random effects pooled & & & 100 & 0.96 (0.85 to 1.08$)$ \\
\hline Heterogeneity $Q=21.0, d f=50, P=1.0$ & & & & \\
\hline & 0.10 .20 .51 & 2510 & 0 & \\
\hline
\end{tabular}

Fig 1 Odds of death and pooled odds ratios in short term trials (arrows indicate 95\% confidence intervals exceeding range of plot). ISIS-1=first international study of infarct survival; TIMI IIB=thrombolysis in myocardial infarction phase II trial; MIAMI=metoprolol in acute myocardial infarction; CPRG=Coronary Prevention Research Group; ICSG=International Collaborative Study Group; UKCSG=UK Collaborative Study Group

tions, and withdrawals. Data were checked by a second researcher.

\section{Statistical analysis}

We estimated pooled odds ratios for short and long term treatment trials separately using the fixed effects approach of Mantel Haenszel. ${ }^{78}$ As we anticipated systematic differences between the results of studies (heterogeneity), we also routinely estimated random effects pooled odds ratios. Standard random effects methods for meta-analysis (pooling the results of studies) ${ }^{9}{ }^{10}$ may provide unduly precise estimates of effect, as they assume that the observed distribution of effects is the true treatment distribution-an assumption that may not be valid in sparse data. ${ }^{511}{ }^{12}$ Therefore, we used the full random effects approach on the basis of the numerical integration techniques using Markov chain Monte Carlo simulation, with appropriate uninformative priors and the "Bugs" software described by Smith et al. ${ }^{5}$ This provides a more robust estimate of the precision of random effects estimates and can account for trial groups that experience no events without resorting to crude fixes such as adding a value to each cell to estimate an individual odds ratio. A further advantage of this approach is that the effects of predictive factors may be examined. Our main treatment related covariates were cardioselectivity and intrinsic sympathomimetic activity, which were examined in the long term trials using a nested random effects logistic regression model (see appendix).

We also made a separate examination of the effects of initial intravenous treatment in long term trials, and the effect of additional treatment options through the proxy variable of publication date before or after the median year (1982). We assessed convergence using the methods described by Geweke ${ }^{13}$ and visual inspection of convergence plots.

We calculated risk differences using standard random effects methods, ${ }^{11}$ and because comparison of risk differences between trials may be affected by different lengths of follow up, we also estimated a pooled incidence risk difference using the approach described by Ioannidis et al. ${ }^{14}$ This is less robust than the pooled odds ratio but provides a practically interpretable estimate of absolute treatment effect derived directly from the trials. ${ }^{15}$ For the long term trials, we also calculated pooled estimates of effect for each $\beta$ blocker using the fixed effects model. ${ }^{78}$

\section{Results}

We identified 82 randomised trials that examined the effects of $\beta$ blockers compared with control and that had data on all cause mortality. Overall, 5477 of 54234 patients $(10.1 \%)$ randomised died. Fifty one trials examined acute treatment with $\beta$ blockers - up to 6 weeks after onset of pain (table 1, and 31 trials examined long term treatment with $\beta$ blockers -6 to 48 months (table 2).

\section{Short term trials}

Overall, 3062 of 29260 patients (10.5\%) randomised in short term trials died. Although 51 trials were identified that examined the effects of short term treatment, only 45 of these had observed deaths in either the intervention or control groups. The major challenge to the quality of this group of trials was that small numbers of patients randomised to treatment or control led to many trials with either no, or only a small number of, deaths.

The pooled random effects odds ratio for the short term trials was 0.96 (95\% confidence interval 0.85 to 1.08); that is, a small and non-significant reduction in the odds of death (fig 1). Even if this result is correct it would represent a reduction of only 0.4 deaths in 100 patients, which does not achieve conventional levels of significance ( -0.2 to 1 ) as 250 patients would require treatment to avoid one death (100 to $\infty)$. Analysis of predicted benefit by drug identified no individual drug that differed significantly in effect from the pooled result.

Although most trials were undertaken before the second international study of infarct survival in $1988^{16}$ firmly established the importance of thrombolysis, a large trial of thrombolysis in myocardial infarction in $1989^{17}$ randomised patients who had received recombinant tissue plasminogen activator within 4 hours of 
Table 2 Characteristics of long term trials comparing $\beta$ blockers with control (see website for references)

\begin{tabular}{|c|c|c|c|c|c|c|c|c|c|c|c|c|c|}
\hline \multirow[b]{2}{*}{ Trial } & \multirow{2}{*}{$\begin{array}{l}\text { Average } \\
\text { follow up }\end{array}$} & \multirow[b]{2}{*}{ Drug* } & \multirow[b]{2}{*}{ Blinding } & \multirow{2}{*}{$\begin{array}{l}\text { Concealment } \\
\text { of allocation }\end{array}$} & \multirow{2}{*}{$\begin{array}{l}\text { Loss to } \\
\text { follow up } \\
(\%)\end{array}$} & \multirow{2}{*}{$\begin{array}{l}\text { Outcome or } \\
\text { endpoint }\end{array}$} & \multirow{2}{*}{$\begin{array}{l}\text { Heart } \\
\text { failure (\%) }\end{array}$} & \multicolumn{2}{|c|}{ Mortality (No/total No) } & \multicolumn{2}{|c|}{ No of reinfarctions } & \multicolumn{2}{|c|}{ No of withdrawals } \\
\hline & & & & & & & & $\beta$ blockers & Controls & $\beta$ blockers & Controls & $\beta$ blockers & Controls \\
\hline $\begin{array}{l}\text { Ahlmark } \\
1974^{\text {w49 }}\end{array}$ & 2 years & Alprenolol & Unclear & Unclear & Unclear & $\begin{array}{l}\text { Mortality, } \\
\text { reinfarction }\end{array}$ & Unclear & $5 / 69$ & $11 / 93$ & 4 & 15 & 4 & 6 \\
\hline $\begin{array}{c}\text { Andersen } \\
1979^{w 50}\end{array}$ & $\begin{array}{l}\text { About } 1 \\
\text { year }\end{array}$ & Alprenolol & Double & Unclear & 0 & Mortality & Unclear & $61 / 238$ & $64 / 242$ & - & - & 59 & 49 \\
\hline Boissel 1990"w51 & 318 days & Acebutolol & Double & Yes & 0 & Mortality & 49.5 & $17 / 298$ & $34 / 309$ & - & - & 102 & 109 \\
\hline $\begin{array}{l}\text { Aronow } \\
1997^{\text {w52 }}\end{array}$ & 1 year & Propranolol & Unclear & Unclear & Unclear & $\begin{array}{l}\text { Mortality, } \\
\text { reinfarction }\end{array}$ & 100 & $44 / 79$ & $60 / 79$ & 3 & 5 & - & - \\
\hline $\begin{array}{l}\text { Australian and } \\
\text { Swedish } \\
\text { study } \\
1983^{\text {w53 }}\end{array}$ & 2 years & Pindolol & Double & Unclear & Unclear & $\begin{array}{l}\text { Mortality, } \\
\text { reinfarction }\end{array}$ & $\begin{array}{l}61 \text { left } \\
\text { ventricular } \\
\text { dysfunction }\end{array}$ & $45 / 263$ & $47 / 266$ & 12 & 13 & 76 & 50 \\
\hline Baber $1980^{\mathrm{w5} 4}$ & 9 months & Propranolol & Double & Unclear & Unclear & $\begin{array}{l}\text { Mortality, } \\
\text { reinfarction }\end{array}$ & Unclear & $28 / 355$ & $27 / 365$ & 17 & 27 & 82 & 88 \\
\hline Barber $1967^{\text {w5 }}$ & 2 years & Practolol & Unclear & Unclear & Unclear & $\begin{array}{l}\text { Mortality, } \\
\text { reinfarction }\end{array}$ & 26 & $33 / 207$ & $38 / 213$ & - & - & - & - \\
\hline Basu $1997^{w 56}$ & 6 months & Carvedilol & Double & Unclear & 0 & $\begin{array}{l}\text { Mortality, } \\
\text { reinfarction }\end{array}$ & 45 & $2 / 75$ & $3 / 71$ & 4 & 8 & - & - \\
\hline BHAT $1982^{\text {w57 }}$ & $\begin{array}{l}25 \\
\text { months }\end{array}$ & Propranolol & Double & Yes & 0.3 & Mortality & 9.2 & $138 / 1916$ & $188 / 1921$ & 103 & 121 & 243 & 179 \\
\hline Darasz 1995w58 & 6 months & Xamoterol & Double & Unclear & 19 & $\begin{array}{l}\text { Mortality, } \\
\text { reinfarction }\end{array}$ & & $3 / 23$ & $1 / 24$ & - & - & 3 & 6 \\
\hline EIS $1984^{\text {w59 }}$ & 1 year & Oxprenolol & Double & Unclear & Unclear & $\begin{array}{l}\text { Mortality, } \\
\text { Reinfarction }\end{array}$ & 7.7 & $57 / 853$ & $45 / 883$ & 36 & 38 & 275 & 275 \\
\hline $\begin{array}{l}\text { Hansteen } \\
1982^{\text {w60 }}\end{array}$ & 1 year & Propranolol & Double & Unclear & 0 & $\begin{array}{l}\text { Mortality, } \\
\text { reinfarction }\end{array}$ & $\begin{array}{l}5.9 \text { (taking } \\
\text { digitalis) }\end{array}$ & $25 / 278$ & $37 / 282$ & 16 & 21 & 70 & 72 \\
\hline $\begin{array}{c}\text { Hjalmarson } \\
1981^{\text {w61 }}\end{array}$ & 2 years & Metoprolol* & $\begin{array}{l}\text { Double } \\
\text { ( } 3 \text { months) } \\
\text { then open } \\
\text { treatment } \\
\text { (to } \\
2 \text { years) }\end{array}$ & Unclear & 1.6 & $\begin{array}{l}\text { Mortality at } 2 \\
\text { years; } \\
\text { reinfarction } \\
\text { at } 3 \text { months }\end{array}$ & 10 & $40 / 698$ & $62 / 697$ & 35 & 54 & 131 & 131 \\
\hline Julian $1982^{\text {w62 }}$ & $\begin{array}{l}12 \\
\text { months }\end{array}$ & Sotalol & Double & Yes & 0 & $\begin{array}{l}\text { Mortality, } \\
\text { reinfarction }\end{array}$ & 0 & $64 / 873$ & $52 / 583$ & 37 & 38 & 218 & 121 \\
\hline Kaul 1988w63 & 6 months & $\begin{array}{l}\text { Propranolol } \\
\text { (iv) }\end{array}$ & Double & Unclear & 0 & $\begin{array}{l}\text { Mortality, } \\
\text { reinfarction }\end{array}$ & Unclear & $3 / 25$ & $3 / 25$ & 0 & 4 & 0 & 0 \\
\hline $\begin{array}{l}\text { LIT Research } \\
\text { Group } \\
1987^{\text {w64 }} \\
\end{array}$ & $\begin{array}{l}18 \\
\text { months }\end{array}$ & Metoprolol & Double & Unclear & 0.2 & Mortality & 2.1 & $86 / 1195$ & $93 / 1200$ & - & - & 381 & 355 \\
\hline $\begin{array}{c}\text { Manger Cats } \\
1983^{\text {w65 }} \\
\end{array}$ & 1 year & Metoprolol & Double & Unclear & 0 & Mortality & Unclear & $9 / 273$ & $16 / 280$ & - & - & - & - \\
\hline Mazur 1984,66 & 1.5 years & Propranolol & No & Unclear & Unclear & $\begin{array}{l}\text { Mortality, } \\
\text { reinfarction }\end{array}$ & Unclear & $5 / 101$ & $11 / 103$ & 5 & 7 & - & - \\
\hline $\begin{array}{l}\text { Multicentre } \\
\quad \text { international } \\
1975^{\text {w67 }}\end{array}$ & $\begin{array}{l}\text { Up to } 24 \\
\text { months }\end{array}$ & Practolol & Double & Unclear & 3.4 & $\begin{array}{l}\text { Mortality, } \\
\text { reinfarction }\end{array}$ & 0 & $102 / 1533$ & $127 / 1520$ & 69 & 89 & 389 & 382 \\
\hline $\begin{array}{l}\text { Norwegian } \\
\text { Multicentre } \\
\text { Study Group } \\
1981^{\text {w68 }}\end{array}$ & $\begin{array}{l}17 \\
\text { months }\end{array}$ & Timolol & Double & Unclear & Unclear & Mortality & 33 & $98 / 945$ & $152 / 939$ & 88 & 141 & 275 & 219 \\
\hline $\begin{array}{c}\text { Rehnqvist } \\
1980^{\text {w69 }} \\
\end{array}$ & 1 year & Metroprolol & Unclear & Unclear & 0 & Mortality & Unclear & $4 / 59$ & $6 / 52$ & - & - & 12 & 5 \\
\hline $\begin{array}{r}\text { Rehnqvist } \\
1983^{\text {w70 }} \\
\end{array}$ & $\begin{array}{l}36 \\
\text { months }\end{array}$ & Metoprolol & Double & Unclear & 0 & $\begin{array}{l}\text { Mortality, } \\
\text { reinfarction }\end{array}$ & $\begin{array}{l}24 \text { (taking } \\
\text { digitalis) }\end{array}$ & $25 / 154$ & $31 / 147$ & 18 & 31 & 38 & 35 \\
\hline $\begin{array}{c}\text { Reynolds } \\
1972^{w 71} \\
\end{array}$ & 1 year & Alprenolol & Double & Yes & Unclear & $\begin{array}{l}\text { Mortality, } \\
\text { reinfarction }\end{array}$ & Unclear & $3 / 38$ & $3 / 39$ & 3 & 2 & 4 & 3 \\
\hline Roqué $1987^{\text {w72 }}$ & $\begin{array}{l}24 \\
\text { months }\end{array}$ & Timolol $^{*}$ & Double & Unclear & Unclear & Mortality & Unclear & $7 / 102$ & $12 / 98$ & - & - & - & - \\
\hline $\begin{array}{l}\text { Salathia } \\
1985^{\text {w73 }} \\
\end{array}$ & 1 year & Metoprolol* & Double & Unclear & 0.5 & Mortality, & 10 & $49 / 416$ & $52 / 348$ & - & - & 95 & 66 \\
\hline $\begin{array}{l}\text { Schwartz } 1992 \\
\text { (high risk } \\
\text { and low } \\
\text { risk) }^{\text {w74 }}\end{array}$ & $\begin{array}{l}22 \\
\text { months }\end{array}$ & Oxprenolol & $\begin{array}{l}\text { High risk† } \\
\text { and low } \\
\text { riskf } \\
\text { groups }\end{array}$ & Unclear & 0 & $\begin{array}{l}\text { Mortality, } \\
\text { reinfarction }\end{array}$ & $\begin{array}{l}2 \text { in high } \\
\text { risk group; } \\
\text { unclear for } \\
\text { low risk } \\
\text { group }\end{array}$ & $\begin{array}{c}2 / 48 \\
15 / 437\end{array}$ & $\begin{array}{l}12 / 56 \\
27 / 432\end{array}$ & 0 & 2 & 11 & 9 \\
\hline SSSD $1993^{\text {w75 }}$ & 3 years & Metoprolol & No & Unclear & 1.9 & $\begin{array}{l}\text { Mortality, } \\
\text { reinfarction }\end{array}$ & 100 & $17 / 130$ & $9 / 123$ & 5 & 6 & - & - \\
\hline Taylor $1982^{\text {w76 }}$ & $\begin{array}{l}48 \\
\text { months }\end{array}$ & Oxprenolol & Double & Done & Unclear & $\begin{array}{l}\text { Mortality, } \\
\text { reinfarction }\end{array}$ & 0 & $60 / 632$ & $48 / 471$ & 67 & 58 & 185 & 141 \\
\hline $\begin{array}{l}\text { Wilcox } \\
1980 a^{\text {w77 }} \\
\end{array}$ & 1 year & $\begin{array}{l}\text { Propranolol* } \\
\text { or atenolol }\end{array}$ & Double & Done & 0 & Death & Unclear & $\begin{array}{l}19 / 127 \\
17 / 132 \\
\end{array}$ & $19 / 129$ & - & - & 4451 & 4040 \\
\hline $\begin{array}{l}\text { Wilhelmsson } \\
1974^{\text {w78 }}\end{array}$ & 2 years & Alprenolol & Double & Unclear & 7 & Mortality & Unclear & $7 / 114$ & $14 / 116$ & 16 & 18 & 8 & 8 \\
\hline Yusuf $1979^{\text {w79 }}$ & $\begin{array}{l}12 \\
\text { months }\end{array}$ & Atenolol & Double & Unclear & 23 & $\begin{array}{l}\text { Death; } \\
\text { electrocardiogr } \\
\text { aphic signs }\end{array}$ & Unclear & $1 / 11$ & $1 / 11$ & - & - & 2 & 1 \\
\hline
\end{tabular}

BHAT= $\beta$-blocker heart attack trial; LIT=lopressor intervention. *Initial dose intravenously. $†$ Single blind. $\ddagger$ Double blind. 
Trial

Boissel 1990w51

Acebutolol pooled

Reynolds 1972 w72

Ahlmark 1974 w49

Wilhelmsson 1974w79

Andersen 1979 w50

Alprenolol pooled

Wilcox 1980aw78

Yusuf 1979w80

Atenolol pooled

Basu 1997 w56

Carvedilol pooled

Rehnqvist $1980^{\text {w70 }}$

López 1993w75

Manger Cats 1983w6

Rehnqvist 1984w71

Salathia 1985 w73

LIT Research Group 1987w64

Hjalmarson 1981w61

Metoprolol pooled

European infarction study 1984 w58

Schwartz 1992 ${ }^{\text {w74 }}$ (high risk)

Schwartz 1992w74 (low risk)

Taylor $1982^{\text {w76 }}$

Oxprenolol pooled

Australian and Swedish study 1983 w53

Pindolol pooled

Barber 1967w55

Multicentre international study 1975w67

Practolol pooled

Kaul 1988w63

Mazur 1984w66

Wilcox 1980aw78

Baber 1980 w54

Aronow 1997 w52

Hansteen $1982^{\text {w60 }}$

BHAT Trial Research Group 1982w57

Propranolol pooled

Julian 1982w62

Sotalol pooled

Roqué 1987 w77

Norwegian Multicentre Study Group 1981w68

Timolol pooled

Darasz 1995 w69

Xamoterol pooled

Fixed effects pooled

Full random effects pooled

Heterogeneity $Q=39.7, d f=32, P=0.16$

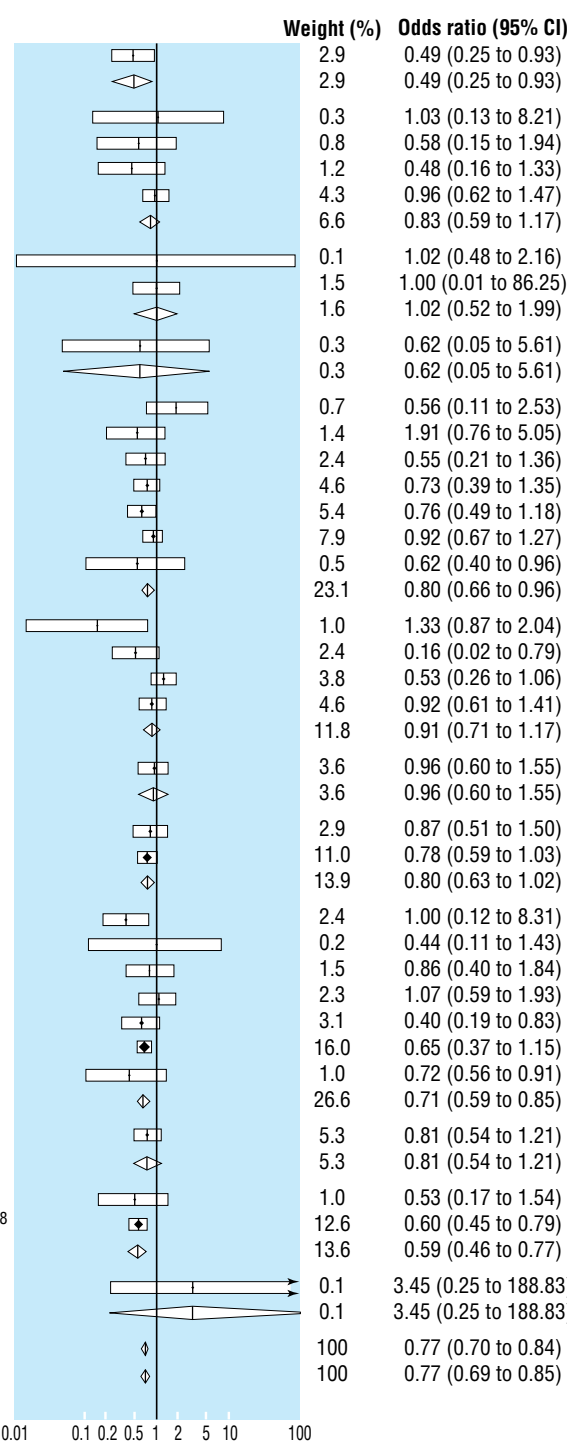

Fig 2 Odds of death and pooled odds ratios in long term trials. LIT=lopressor intervention; $\mathrm{BHAT}=\beta$-blocker heart attack trial across the trials. This approach suggests an annual reduction of 1.2 deaths in 100 patients treated with $\beta$ blockers after myocardial infarction ( 0.6 to 1.7$)$; that is, about 84 patients will require treatment for 1 year to avoid one death. A similar approach was used to estimate the effects of treatment on reinfarction, although only 21 of the 34 comparisons provided data on reinfarction, resulting in wider confidence intervals and the potential for reporting bias. This analysis suggests an annual reduction in reinfarction of 0.9 events in every 100 (0.3 to 1.6$)$; that is, about 107 patients would require treatment for 1 year to avoid one non-fatal reinfarction.

\section{Predictors of benefit}

Initial intravenous dose-We investigated the extent to which initiation of treatment with an intravenous dose of $\beta$ blockers predicted mortality in the long term trials. Applying initial intravenous dose as a covariate term in the analysis suggested no additional benefit among patients treated in this manner (odds ratio 0.87, 0.61 to 1.22 ). Equally, this analysis indicates that there is no reason to delay treatment with a $\beta$ blocker and that early initiation will lead to a greater period when benefits may be accrued from treatment.

Presence of cardioselectivity or intrinsic sympathomimetic activity-We anticipated that the presence of cardioselectivity and intrinsic sympathomimetic activity would be important predictors of benefit in the trials, a hypothesis examined by Yusuf et al. ${ }^{4}$

Classification of $\beta$ blockers into those with or without important cardioselective activity or intrinsic sympathomimetic effect is not clear cut, and there is some debate in the literature on the attributes of acebutolol in particular. ${ }^{18-20}$ Table 3 describes the attributes of $\beta$ blockers used in the trials.

The odds ratio for the predictive effect of cardioselectivity on mortality was 1.10 (0.89 to 1.39 ), showing a non-significant trend towards reduced benefits. The odds ratio for the predictive effect of the presence of intrinsic sympathomimetic activity was 1.19 (0.96 to 1.47 ), which approaches statistical significance. The results were not sensitive to the classification of acebutolol.

Reduction of benefits over time-We investigated whether benefits were reduced in the trials with additional therapeutic options for treatment intro-

During 5 days of follow up, there was no difference in mortality between the two groups. Two subsequent myocardial infarctions were, however, avoided for every 100 patients treated ( 0.2 to 4$)$.

\section{Long term trials}

Overall effects

Overall, 2415 of 24974 patients $(9.7 \%)$ randomised in the 31 long term trials died. In general, the quality of studies was reasonably high, with adequate follow up achieved in many trials (table 2), though the proxy quality variable, concealment of allocation, was seldom adequately reported.

Overall, the pooled odds ratio from the full random effects model was 0.77 (0.69 to 0.85 ). Results from the standard fixed effects model were similar (fig 2).

Because of potential confounding due to the differences in length of study follow up, we used the random effects approach for incidence of risk difference to estimate the normalised annual reduction in mortality
Table 3 Classification of attributes of different $\beta$ blocker drugs

\begin{tabular}{lcc}
$\beta$ Blocker & Cardioselectivity & $\begin{array}{c}\text { Intrinsic sympathomimetic } \\
\text { activity }\end{array}$ \\
\hline Acebutolol & - & - \\
\hline Alprenolol & - & + \\
\hline Atenolol & + & - \\
\hline Betaxolol & + & - \\
\hline Carvedilol & - & - \\
\hline Labetalol & - & - \\
\hline Metoprolol & + & - \\
\hline Oxprenolol & - & + \\
\hline Pindolol & - & + \\
\hline Practolol & + & + \\
\hline Propranolol & - & - \\
\hline Sotalol & - & - \\
\hline Timolol & - & + \\
\hline Xamoterol & + & - \\
\hline
\end{tabular}

+=Significant activity; -=no significant activity. 
duced, in particular the increasing use of thrombolytic treatment, and aspirin. There is no evidence that treatment in trials after 1982 (the median trial) led to differences in benefit (odds ratio 1.04, 0.82 to 1.28 ).

Choice of drug-Individually, only four drugs achieved a statistically significant reduction in the odds of death: propranolol (0.71, 0.59 to 0.85$)$; timolol (0.59, 0.46 to 0.77$)$; metoprolol $(0.80,0.66$ to 0.96$)$; and acebutolol $(0.49,0.25$ to 0.93$)$. The effectiveness of acebutolol is supported by a single moderately sized study, which is open to considerable measurement error However, trials including propranolol, timolol, and metoprolol include $63 \%$ of the available evidence on the effects of long term $\beta$ blockade in patients who have had a myocardial infarction.

\section{Withdrawal from treatment}

Different definitions and reporting made comparison of withdrawal of treatment withdrawal between trials problematic. Similar withdrawal rates between active treatment and placebo groups concealed two opposing effects: more patients are withdrawn from treatment groups because of suspected adverse cardiovascular reactions (most commonly brachycardia and hypotension), whereas in the placebo group withdrawal is more common because of the need for $\beta$ blockade for hypertension and angina. Trials reports of dizziness, depression, cold extremities, and fatigue were only marginally more common in the treatment than control groups.

Withdrawal in trials from both treatment and control groups varied from $10 \%$ to $30 \%$. No adequate studies have been retrieved to compare directly the comparative tolerability of $\beta$ blockers with different cardioselectivity or intrinsic sympathomimetic activity.

Overall, 5151 of 21954 patients (23.5\%) withdrew from treatment (table 2). Overall, withdrawal was slightly more common in patients taking $\beta$ blockersthe difference in the annualised rate of withdrawal compared with placebo being 1.16 in 100 patients treated ( 0.56 to 1.76 , random effects; fig 3$)$. No clinically important differences in withdrawal were observed between $\beta$ blockers of differing cardioselectivity and intrinsic sympathomimeticity.

\section{Discussion}

Considerable evidence supports the routine long term use of $\beta$ blockers in patients who have had a myocardial infarction, with substantial benefits in terms of reduced mortality and morbidity. Short term $\beta$ blockade immediately after acute myocardial infarction seems unlikely to be of major benefit unless treatment is continued long term. This finding contradicts recent suggestions that $\beta$ blockers should be more commonly used intravenously in acute myocardial infarction. ${ }^{21}$ In fact, evidence strongly indicates that unless $\beta$ blockers are continued long term, the benefits suggested by Owen ${ }^{21}$ will not be observed.

The benefits of $\beta$ blockers on all cause mortality are impressive when compared with other frequently used long term treatments for the same patient group. Table 4 shows the effects of different drugs on the number of patients that would need to be treated for 2 years to avoid one death-for example, after a myocardial infarction 42 patients would need to be treated with $\beta$

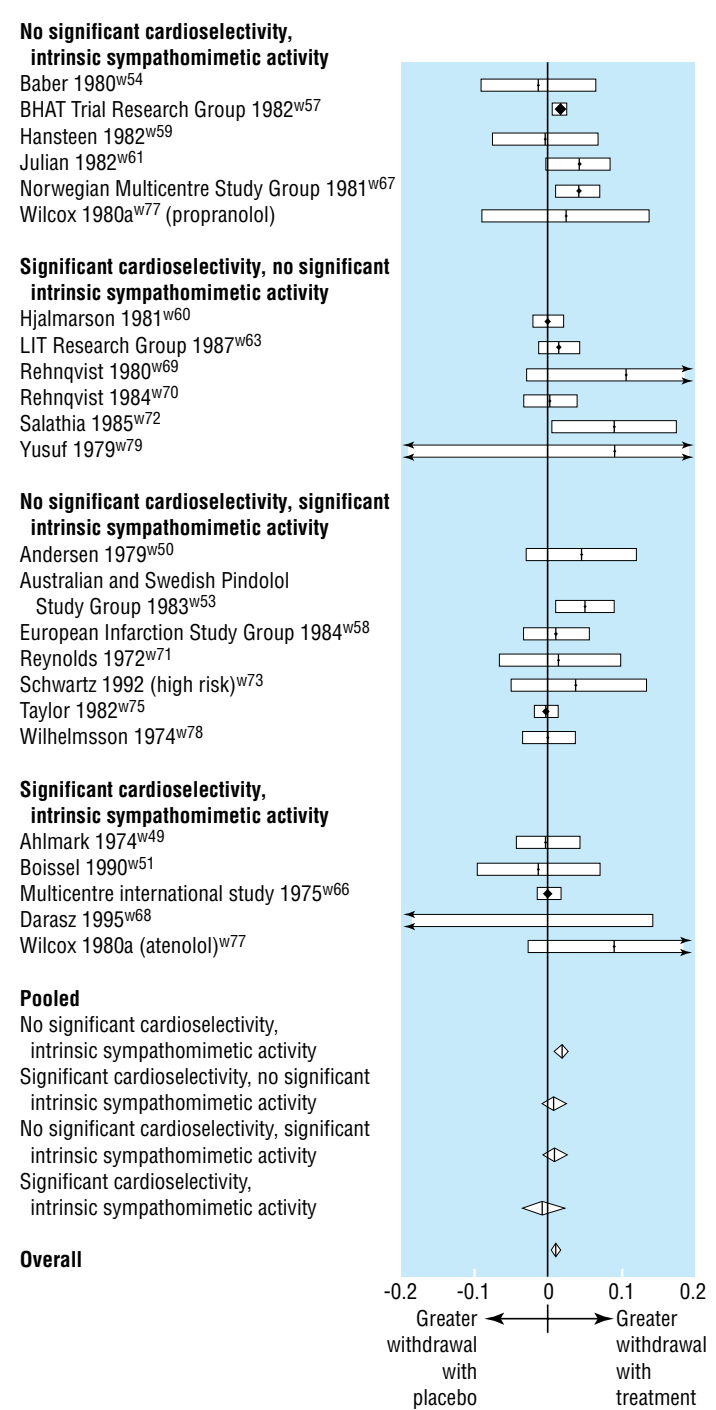

Pooled incident risk difference $=0.0116(95 \% \mathrm{Cl} 0.0056$ to 0.0176$)$ $Q$ (combinability for risk difference) $=22.7, d f=21, P=0.478$

Fig 3 Incidence (yearly) of withdrawal from trials

Table 4 Comparison of effect on mortality of different drugs

\begin{tabular}{lc} 
Drug & $\begin{array}{c}\text { Number needed to treat* } \\
\text { * }\end{array}$ \\
\hline $\begin{array}{l}\text { Anglockers } \\
\text { inhibitors converting enzyme }\end{array}$ & 42 \\
\hline $\begin{array}{l}\text { Antiplatelet agent } \\
{ }^{22}\end{array}$ & $\begin{array}{c}\text { No long term trials in unselected } \\
\text { patients }\end{array}$ \\
\hline Statin $^{29}$ & 153 \\
\hline Calcium channel blockers (diltiazem) $^{30}$ & 94 \\
\hline Thrombolysis and aspirin for 4 weeks $^{16}$ & $\infty$ \\
\hline Warfarin $^{3132}$ & 24 \\
\hline
\end{tabular}

*Number needed to avoid death in 2 years of treatment in unselected patients after myocardial infarction.

blockers whereas 292 patients would need to be treated with antiplatelets. ${ }^{22}$ The number and length of long term trials showing a consistent benefit for $\beta$ blockers in unselected patients after myocardial infarction suggest lasting benefits in this comparatively high risk group, and suggest that $\beta$ blockers should be continued indefinitely. 
Have benefits from $\beta$ blockade declined with availability of new treatments?

Our finding that $\beta$ blockers benefit a broader group of patients after myocardial infarction supports the findings of the $\beta$ blocker pooling project. ${ }^{23}$ Our finding also agrees with those of the cooperative cardiovascular project, which examined the medical records of 201752 patients who had had a myocardial infarction. ${ }^{24}$ In that study, mortality was lower in every subgroup of patients treated with $\beta$ blockade than in untreated patients. The findings of the cooperative cardiovascular project agree with our meta regression analysis, which found no evidence of a reduction in benefits from $\beta$ blockade in more recent randomised trials. Indeed, rather than being overtaken by newer treatments, $\beta$ blockers have a comparatively large effect in reducing mortality (table 4).

\section{Which $\beta$ blocker?}

Cardioselectivity was associated with a non-significant trend towards reduced benefit. The presence of an intrinsic sympathomimetic effect predicted a near significant reduction in benefits and thus drugs with this characteristic should be avoided. We found evidence to support the long term use of propranolol and timolol, the only two drugs indicated for prophylaxis after myocardial infarction in the British National Formulary. The use of either drug led to a substantial reduction in the odds of death, with narrow confidence intervals (fig 2). In contrast, atenolol, which is commonly prescribed in secondary prevention, has been inadequately evaluated in this setting. Although similar efficacy may be achieved-we found no evidence that all $\beta$ blockers are not equal-it cannot be presumed that the benefits from propranolol, timolol, and metoprolol will be achieved with other drugs.

\section{Have benefits from intravenous $\beta$ blockers declined over time?}

It may be hypothesised that intervention with thrombolytic drugs and antiplatelets reduces the potential for patients to benefit from intravenous $\beta$ blockade. The first international study of infarct survival $^{25}$ was completed before the results of the second international study ${ }^{16}$ became available, and before the use of thrombolytic and antiplatelet treatment was established. In contrast, the comparison of early versus delayed $\beta$ blockade in a large trial of thrombolysis in myocardial infarction was undertaken in patients who all received thrombolytic and antiplatelet treatment. ${ }^{17}$ Although the much larger first international study of infarct survival trial ${ }^{25}$ achieved a slightly larger reduction in the odds of death with $\beta$ blockers, measurement error could not be excluded as an explanation for this difference, as indicated by the test for heterogeneity between the trials $(Q=0.025$, $\mathrm{df}=1, \mathrm{P}=0.87$ ). The thrombolysis in myocardial infarction trial did suggest that early use of intravenous $\beta$ blockers could reduce the early risk of serious arrhythmias.

\section{Are $\beta$ blockers underused?}

Concern has been voiced that $\beta$ blockers are used in less than half of eligible patients after myocardial infarction, ${ }^{1-3}$ despite substantial benefits and generally low treatment costs. Concern that side effects affect the
- The first randomised trials of $\beta$ blockade in secondary prevention after myocardial infarction were published in the $1960 \mathrm{~s}$

- $\beta$ blockers were once heralded as a major advance, but their use for secondary prevention has declined in recent years

- Firm evidence shows that long term $\beta$ blockade remains an effective and well tolerated treatment that reduces mortality and morbidity in unselected patients after myocardial infarction

- The benefits from $\beta$ blockade compare favourably with other drug treatments for this patient group

- Most evidence is for propranolol, timolol, and metoprolol, whereas atenolol, which is commonly used, is inadequately evaluated for long term use

usefulness of $\beta$ blockers must be tempered by the low yearly withdrawal from $\beta$ blockers in the long term trials we reviewed. The clinical implications of our results are clear. New is not necessarily better, especially if the aim is to reduce mortality in patients after myocardial infarction. Furthermore, the underuse of $\beta$ blockers in this group leads to a rate of avoidable death that should not be considered acceptable among those keen to practice evidence based medicine.

Renewed interest in $\beta$ blockers, particularly in patients with heart failure, ${ }^{26-28}$ may lead to substantial benefits for a broad range of patients.

We thank Andrew Herxheimer, who assisted in the categorisation of included compounds, and Anne Burton for her diligent help in locating studies and in the preparation of the manuscript.

Contributors: NF developed the protocol for the review, abstracted data, and undertook the majority of statistical analyses. JC conceptualised the review, developed the protocol, and provided clinical interpretation of the included trials and the results. PY developed the meta regression approach and provided methodological support in the review. JM contributed to the development of the protocol, data abstraction, and some of the statistical analyses. $\mathrm{JH}$ designed and implemented the electronic search strategies. NF and JC will act as guarantors for the paper.

Funding: SmithKline Beecham Pharmaceuticals UK. The views expressed are those of the authors and not necessarily those of the sponsor.

Competing interests: This study was funded through an unrestricted educational grant by SmithKline Beecham, who supply carvedilol in the United States. JGFC has spoken at many meetings and educational programmes on drugs in heart failure, organised by pharmaceutical and device companies, and received fees and expenses. He has also received research funding from industry as well as the NHS, British Heart Foundation, and US Veterans Administration.

\section{Appendix}

Statistical model for random effects regression analysis

$\log \left(\frac{p t}{1-p t}\right)=\alpha+\delta+\beta I+\gamma S$

$\log \left(\frac{p c}{1-p c}\right)=\alpha$

Where $p t$ is the probability of an event in the intervention group, $p c$ is the probability of an event in the control group, 
$I$ is the presence or absence of significant intrinsic sympathomimetic activity, and $S$ is the presence or absence of significant cardioselectivity. Similarly, $\alpha$ is a constant, $\delta$ describes the overall treatment effect, $\beta$ describes the effect of intrinsic sympathomimetic activity, and $\gamma$ describes the effect of cardioselectivity.

1 Smith J, Channer KS. Increasing prescription of drugs for secondary prevention after myocardial infarction. BMJ 1995;311:917-8.

2 Eccles M, Bradshaw C. Use of secondary prophylaxis against myocardial infarction in the north of England. BMJ 1991:302:91-2.

3 Viskin S, Barron HV. $\beta$-Blockers prevent cardiac death following myocardial infarction: so why are so many infarct survivors discharge withou $\beta$-blockers? Am J Cardiol 1996;78:821-2.

4 Yusuf S, Peto R, Lewis J, Collins R, Sleight P. $\beta$-Blockade during and after myocardial infarction: an overview of the randomized trials. Prog Cardiovasc Dis 1985;27:335-71.

5 Smith TC, Spiegelhalter DJ, Thomas A. Bayesian approaches to randomeffects meta analysis: a comparative study. Stats Med 1995;14:2685-99.

6 Schulz KF, Chalmers I, Hayes RJ, Altman DG. Empirical evidence of bias: dimensions of methodological quality associated with estimates of treatment effects in controlled trial. JAMA 1995;273:408-12.

7 Rothman KJ. Modern epidemiology. Boston: MA Little and Brown, 1986.

8 Robins J, Breslow N, Greenland S. Estimators of the Mantel-Haenszel variance consistent in both sparse data and large strata models. Biometric 1986;42:311-23.

9 Fleiss J, Gross AJ. Meta-analysis in epidemiology, with special reference to studies of the association between exposure to environmental tobacco smoke and lung cancer: a critique. J Clin Epidemiol 1991;44:127-39.

10 DerSimonian R, Laird N. Meta-analysis in clinical trials. Controlled Clin Trials 1986;7:177-88.

11 Carlin JB. Meta analysis for $2 \beta 2$ tables: a Bayesian approach. Stats Med $1992 ; 11: 141-58$

12 Hardy RJ, Thompson SG. A likelihood approach to meta analysis with random effects. Stats Med 1996;15:619-29.

13 Spiegelhalter D, Thomas A, Best N, Gilks W. BUGS: Bayesian inference using Gibbs sampling, Version 0.50. Cambridge: Medical Research Council Biostatistics Unit, 1995

14 Ioannidis JPA, Cappelleri JC, Lau J, Skolnik PR, Melville B, Chalmers TC, et al. Early or deferred zidovudine therapy in HIV-infected patients without an AIDS defining illness. Ann Intern Med 1995;122:856-66.

15 Freemantle N, Mason JM, Eccles M. Deriving treatment recommendations from evidence within randomised trials: the role and limitation of meta analysis. Intern J Technol Assess Health Care (in press).

6 Second International Study of Infarct Survival Collaborative Group. Randomised trial of intravenous streptokinase, oral aspirin, both or neither among 17187 cases of suspected acute myocardial infarction: ISIS-2, Lancet 1988;ii:349-60.
17 The Thrombolysis in Myocardial Infarction Study Group. Comparison of invasive and conservative strategies after treatment with intravenous tissue plasminogen activator in acute myocardial infarction: results of the thrombolysis in myocardial infarction (TIMI) phase II trial. $N$ Engl J Med 1989:320:618-27.

18 Wilhelmsson C, Vedin JA, Wilhelmsen L, Tibblin G. Reduction of sudden deaths after myocardial infarction by treatment with alprenolol: preliminary results. Lancet 1974;ii:1157-60.

19 Feely J, de Vane PJ, Maclean D. $\beta$-Blockers and sympathomimetics. BMJ 1983;286:1043-7.

$20 \mathrm{McDevitt}$ DG. The assessment of $\beta$-adrenoceptor-blocking drugs in man Br J Clin Pharmacol 1977;4:413-25.

21 Owen A. Intravenous $\beta$-blockade in acute myocardial infarction: should be used in combination with thrombolysis. BMJ 1998;317:226-7.

22 Antiplatelet Trialists' Collaboration. Collaborative overview of randomised trials of antiplatelet therapy. I. Prevention of death, myocardial infarction and stroke by prolonged antiplatelet therapy in various categories of patients. BMJ 1994;308:81-106.

$23 \beta$-Blocker Pooling Project Research Group. The $\beta$-blocker pooling project (BBPP): subgroup findings from randomized trials in post infarction patients. Eur Heart J 1988;9:8-16.

24 Gottlieb SS, McCarter RJ, Vogel RA. Effect of $\beta$-blockade on mortality among high risk and low risk patients after myocardial infarction. $N$ Engl J Med 1998;339:489-97.

25 First International Study of Infarct Survival Collaborative Group Randomised trial of intravenous atenolol among 16027 cases of suspected acute myocardial infarction: ISIS-1. Lancet 1986;ii:57-67.

26 Doughty RN, Rodgers A, Sharpe N, MacMahon S. Effects of $\beta$-blocke therapy on mortality in patients with heart failure: a systematic overview of randomized controlled trials. Eur Heart J 1997;18:560-5

27 Heidenreich PA, Lee TT, Massie BM. Effect of $\beta$-blockade on mortality in patients with heart failure: a meta analysis of randomized clinical trials. J Am Coll Cardiol 1997;30:27-34

28 Cleland JGF, Freemantle N, McGowan J, Clark A. The evidence for $\beta$ blockers in heart failure. $B M J$ 1999;318:824-5.

29 Latest trials on statins show large benefits? Lancet 1997;350:1525

30 The Multicenter Ditiazem Postinfarction Trial (MDPIT) Research Group. The effect of diltiazem on mortality and reinfarction after myocardial infarction. N Enol J Med 1988;319:385-92.

31 Smith P, Arnesen H, Holme I. The effect of warfarin on mortality and reinfarction after myocardial infarction. N Engl J Med 1990;323:147-52.

32 Anticoagulants in the Secondary Prevention of Events in Coronary Thrombosis (ASPECT) Research Group. Effect of long term oral anticoagulant treatment on mortality and cardiovascular morbidity after myocardial infarction. Lancet 1994;343:499-503.

(Accepted 6 April 1999)

\title{
Risk factors for human hantavirus infection: Franco-Belgian collaborative case-control study during 1995-6 epidemic
}

\author{
N S Crowcroft, A Infuso, D Ilef, B Le Guenno, J-C Desenclos, F Van Loock, J Clement
}

Puumala hantavirus is the most common human hantavirus infection in Europe. ${ }^{12}$ It is transmitted to humans by inhalation or contamination of skin breaches by urine or faeces of infected bank voles. Infection ranges from subclinical to a severe influenzalike illness progressing to acute renal failure. ${ }^{3}$ We carried out a case-control study in an endemic area in France and Belgium to estimate knowledge of hantavirus and identify possible risk factors for infection.

\section{Subjects, methods, and results}

National reference laboratories in each country identified cases for the study. A case was defined as someone with laboratory confirmed IgM positive Puumala hantavirus infection between 1 April 1996 and 31 July 1996 in the French departments Nord, Ardennes, and Aisne and Belgian provinces of Hainaut, Namur, and Luxembourg. Controls were matched by sex, community (village), and age group. They were randomly selected from the telephone book. Interviews were carried out by telephone using a standardised question- naire covering knowledge of hantavirus, distance of the home to a forest, refuse disposal, rodent infestation and control, gardening activities, use of wood for heating or cooking, activities in forests, and entry into rodent infested buildings.

In all, 69/88 (78\%) eligible cases were included in the study and 125 controls were recruited. Most cases were in men (51) and those aged 15-65 years (64). Two cases and one control were forestry workers-no others were in occupations thought to be at risk. Forty seven per cent $(91 / 194)$ of those interviewed had heard of hantavirus infection before becoming ill or being interviewed. Friends were the commonest source of information (44/91, 48\%); 63/75 (84\%) had heard of the disease in the past 3 years.

The table shows the results of logistic regression. Cases and controls often went walking in forests (odds ratio $0.5,95 \%$ confidence interval 0.1 to $2.7 ; \mathrm{P}=0.64$ ) Cases were more likely to have entered a building where there might be rodents $(1.9,1.0$ to $3.6 ; \mathrm{P}=0.05)$ and were more likely to have cleaned $(4.2,1.1$ to 15.7 ;
Epidemiology Department, Scientific Institute of Public HealthLouis Pasteur, Brussels, Belgium N S Crowcroft, fellow, European programme for intervention epidemiology training J-C Desenclos, head of infectiou diseases unit

Réseau National de Santé Publique Saint-Maurice,

France

A Infuso,

fellow, European programme for intervention epidemiology training F Van Loock, epidemiologist continued over BMJ 1999;318:1737-8 